\title{
FATHOM
}

\section{Looking at Adders in The Return of the Native}

Regards de vipères dans The Return of the Native

\section{Anna West}

\section{(2) OpenEdition}

\section{Journals}

Electronic version

URL: http://journals.openedition.org/fathom/752

DOI: $10.4000 /$ fathom.752

ISSN: 2270-6798

\section{Publisher}

Association française sur les études sur Thomas Hardy

\section{Electronic reference}

Anna West, "Looking at Adders in The Return of the Native », FATHOM [Online], 5 | 2018, Online since 22 April 2018, connection on 20 April 2019. URL : http://journals.openedition.org/fathom/752 ; DOI : 10.4000/fathom.752

This text was automatically generated on 20 April 2019. 


\title{
Looking at Adders in The Return of the Native
}

\author{
Regards de vipères dans The Return of the Native
}

\section{Anna West}

\section{EDITOR'S NOTE}

This article is being published jointly by FATHOM and the Hardy Review as part of a collaborative work.

In his essay "Why Look at Animals?" (1980) art critic John Berger discusses the gaze between humans and animals. He argues that while the gaze of animals has the power to surprise humans (who see themselves being seen through the animals' eyes), this look has been "extinguished" with the marginalization of animals from society (Berger 37). In Thomas Hardy's novels, humans who encounter animals face-to-face and eye-to-eye often find themselves uncomfortable being seen through the gaze of the animal. In The Return of the Native (1878), for example, Mrs Yeobright shudders under the gaze of the adder. While Berger argues for the importance of metaphor in restoring the human-animal relationship, the adder in the scene can be read not only as a metaphor for the absentyet-implicated Eustacia, but also as a living being in its own right. Of significance to this paper is the refusal of the human-animal gaze that occurs during the encounter: the turning away, or the desire not to see oneself being seen through the eyes of another, a desire that also occurs during interactions between humans in the novel. What happens to desire when the gaze flickers, is deflected, or becomes indifference? Furthermore, how might this affect the way one looks at - or away from - literary animals?

Berger frames his essay with a provocative titular question: why look at animals? Chronicling the human-animal relationship, he posits a history where animals existed with humans at the center of the human world, living alongside them in their homes and working beside them in the fields. In this world before what Berger describes as the process from nineteenth-century industrialization to twentieth-century corporate 
capitalism that utilized Cartesian dualism to transform animal bodies into "machines", "raw material", and eventually "manufactured commodities", Berger describes the gaze between an animal and a human (Berger 23). He writes:

The animal scrutinizes him across a narrow abyss of non-comprehension. This is why the man can surprise the animal. Yet the animal - even if domesticated - can also surprise the man. The man too is looking across a similar, but not identical, abyss of non-comprehension [...] when he is being seen by the animal, he is being seen as his surroundings are seen by him. His recognition of this is what makes the look of the animal familiar. (Berger 13-14)

This ability to return a gaze, to look back, indicates a power on the part of the animal. In the words of Ron Broglio, "[t]raditionally, sight is possession at a distance: we take in to human interiority and reason the object of our gaze. When the animal looks back, the hegemony of human vision becomes confounded" (Broglio 58). The ability to gaze back implies another point of view, and if seeing is a vital way of knowing - a primary empirical process through which knowledge of the material world is acquired - then an animal's ability to look back at a human implies its own way of knowing.

This ability on the part of the animal has a similar effect to Hardy's use of perspective in his writings. As J. Hillis Miller notes, "Hardy is adept at making sudden relatively small shifts in perspective which put his reader virtually, though not actually, at an infinite distance from events - as if they were suddenly seen through the wrong end of a telescope" (Miller 51). The result of these shifts in perspective is that "[t]he reader is made aware that there are two ways of seeing events, a way which takes what is seen as the whole span of reality, and one which sees any perspective as only one among many possibilities and therefore as relative in the value it gives to things" (51). He concludes, "[t]o embrace any view of things with a wider, more inclusive view, or even one merely different, is to put both views in question" (51). The recognition of an animal's gaze back, then, places human perspective in question, gesturing for the possibility of ways of knowing and being outside those valued by humanist tradition. As George Levine has argued, becoming the object of another's gaze is a form of exposure, placing the individual in a vulnerable position. ${ }^{1}$

5 The gaze, then, implies both power and vulnerability - in looking and being looked at even without any further action or speech. Perhaps because of this felt power and exposure, the gaze has been studied as the site of the birthplace of ethical obligation, as can be seen in the writings of twentieth-century philosopher Emmanuel Levinas on faceto-face encounters. He argued that the face - which he defined as "[t]he way in which the other person presents himself, exceeding the idea of the other in $m e$ " - speaks more clearly than speech itself (Levinas 50). In the moment of the gaze, one's "idea of the other" cannot remain an abstraction; it becomes a flesh-and-blood reality. Despite the brevity of the gaze, it communicates in a way speech itself cannot. In Levinas's words, speech "does not have the total transparence of the gaze directed upon the gaze, the absolute frankness of the face to face proffered at the bottom of all speech" (182). He concluded, through the course of his work, that the face-to-face encounter demands ethical obligation to one's neighbour, placing the needs of the other before the self.

6 Yet unlike the power and vulnerability that both the animal and the human experience in a face-to-face encounter, the extension of ethical obligation to the animal in such an encounter was not a given, at least not for Levinas. If the animal could not reciprocate the ethical imperative presented by the gaze - that is, if the animal, unlike the human, could 
not put the needs of the other before the self - then could an animal be said to have a face? Levinas considered this question directly when it was posed to him during an interview with a group of students. Perhaps a dog could have a face - could act in such a way, as arguably the dog who aids Fanny on the Casterbridge highway in Far from the Madding Crowd (1874) behaves - but could a snake? "I don't know if a snake has a face", Levinas responded. "A more specific analysis is needed” (Wright et al. 171-172).

In Hardy's The Return of the Native, such an analysis might be conducted. The novel's focus on faces and its scene showing the encounter between Mrs Yeobright and an adder provide ample material for consideration of the human-animal - and specifically the human-snake - gaze. Having suffered an adder bite on her foot during her exposure on the heath on her attempted walk home from Eustacia and Clym's house, Mrs Yeobright is carried by her son into a hut. A group of heath-folk gathers around her bedside, and they explain that the only cure for the bite requires oil extracted from the fat of other adders to be applied to the wound. Three adders are brought into the hut. Two are dead, but one is still "briskly coiling and uncoiling in the cleft of the stick" upon which it is being carried (Hardy 2005, 285). ${ }^{2}$ The narrator describes the moment:

The live adder regarded the assembled group with a sinister look in its small black eye, and the beautiful brown and jet pattern on its back seemed to intensify with indignation.

Mrs Yeobright saw the creature, and the creature saw her: she quivered throughout, and averted her eyes. (Hardy 2005, 285)

Mrs Yeobright's discomfort at the gaze of the adder is striking: the act of seeing and being seen shakes her thoroughly, and she not only turns away but "avert[s]" her gaze - a verb that implies not only looking away but an attempt to "prevent or ward off (an undesirable occurrence)" (OED). With the previous discussion of the gaze in mind, one might ask, why does Mrs Yeobright react in the way that she does, averting her gaze away from the adder?

If the adder is read as a metaphorical stand-in for Eustacia, then the aversion of the gaze is linked to an earlier encounter between Mrs Yeobright and Eustacia, just before Mrs Yeobright's long walk home across the hot heath. In this person-to-person encounter, Mrs Yeobright sees her daughter-in-law's face framed in the window, looking out at her and turning away without letting her in. Annie Ramel argues that "Eustacia [...] 'kills' her mother-in-law by a Medusa-like gaze, a silent look through a window-pane", noting that the scene between the woman and the adder "clearly repeats the deadly exchange of looks which caused the mother-in-law to walk away in utter desperation, and designates Eustacia, 'the lonesome dark-eyed creature,' as the murderess whose evil eye has stung to death the older woman" (Ramel 2011, 64). Several connections between Eustacia and the adder seem to link the two face-to-face encounters further. The adder's coiling and uncoiling around the stick echoes the "twining and untwining" of Eustacia's thoughts around a "single object" earlier in the novel as she gazes toward Wildeve's house (Hardy 2005, 93). The group around Mrs Yeobright's bed observes the gaze between the adder and the woman, and Christian Cantle exclaims, "'Tis to be hoped he can't ill-wish us!" (285) - a statement that echoes his grandfather's declaration of his willingness to marry Eustacia and "'take the risk of her wild dark eyes ill-wishing me"' in the beginning of the 
novel (52). As Ramel notes, "the 'small black eye' of the adder" seems "a duplicate of Eustacia's 'wild dark eyes' known for their 'ill-wishing power"' (Ramel 2015, 102) ${ }^{3}$.

The superstitious suggestion of "overlooking" and "ill-wishing" - or the idea that the gaze has the potential to carry harm, whether intentional or accidental - does seem to connect Eustacia and the adder through the myth of the snake-haired Medusa, the figure perhaps most associated with the evil eye. But as Jacqueline Dillion and Phillip Mallett point out, the term '“overlooked' suggests a wider but less definite fear than the identifiable 'evil eye', for those who suspect they have been overlooked do not know who has overlooked them - or whether that person (or that animal?) consciously means harm - or whether they may have even unwittingly overlooked themselves" (Dillion \& Mallett). Christian Cantle, in expressing his anxiety that the adder might "ill-wish" them (and justifying Mrs Yeobright's aversion of gaze from a folkloric standpoint), adds that "there's folk in heath who've been overlooked already" (Hardy 2005, 285) ${ }^{4}$. While this statement comments on the "paranoia follow[ing] from the possibility of being watched", it also points to the lack of knowledge as to "who has the power to overlook, ill-wish, or look on with the evil eye" (Dillion \& Mallett 21, emphasis original). In this case, while Mrs Yeobright may recognize the gaze of Eustacia in the adder's eye, she may also be reacting to a power that the adder itself has the possibility of holding, albeit through superstitious belief.

11 Yet just because the aversion may be linked to a superstition does not render that fear as irrational. Dillion argues that Hardy complicates the easy dismissal by the reader of the heath-folk's superstition by framing Christian's anxiety with "another folkloric custom, applying fresh adder fat to an adder bite" (Dillion 24). While this "remedy" may seem outdated - as Clym himself expresses - the doctor who attends Mrs Yeobright notes that the practice has some overlap with scientific knowledge. This mix of fact and folklore - with a difficulty of knowing "which seemingly outlandish folkloric beliefs and practices might nonetheless have some basis in truth", as Dillion explains (24) - makes it difficult to dismiss the heath-folk's worry of overlooking. Similarly, Mrs Yeobright's physical reaction to the adder has a basis in biology. While the "universal abhorrence of these creatures" (to quote Carl Hagenbeck, the infamous exotic animal importer and creator of the modern zoological park) may seem like a stereotypical generalization, psychologist Paul Ekman notes that biologically speaking, humans are predisposed "to respond in a fearful way to snake-like shapes" (Hagenbeck 177; Darwin 44n). Aversion to reptiles is ingrained in the human body. As with Dillion's note on Hardy's depiction of overlooking in his supernatural short story "The Withered Arm", his "portrayal of the act [of overlooking] from a variety of perspectives refuses to privilege any one view of reality" (Dillion 24). The adder may be a metaphorical stand-in for Eustacia through Mrs Yeobright's eyes, or a potential "overlooker" from the heath-folk's point of view, but he is at the same time a literal animal in the scene, behaving in the manner of a snake, with the power to look back, to hold the human as the object of his gaze.

If one considers the rendering of the adder as a "creature" in the act, his gaze does indeed seem to interrupt "the hegemony of human vision" in the scene (Broglio 58). When Hardy uses the term "creature" in his novels to indicate an animal during an interspecies encounter, the depiction of that animal usually interrogates a traditional boundary that would separate the human from the animal: in this case, the dominance of human perspective. As Broglio argues, "[i]n this look from another species, we realize there are more points of view than our own" (67). The repetition in the sentence in which the gaze 
occurs emphasizes the reciprocity of the act: "Mrs Yeobright saw the creature, and the creature saw her" (Hardy 2005, 285). In his essay, "The Animal That Therefore I Am (More to Follow)", Derrida focuses on this act of looking that the animal performs during his encounter with his cat. He notes,

it can allow itself to be looked at, no doubt, but also - something that philosophy perhaps forgets [...] - it can look at me. It has its point of view regarding me. The point of view of the absolute other, and nothing will have ever done more to make me think through this absolute alterity of the neighbor than these moments when I see myself seen naked under the gaze of a cat. (Derrida 380)

this irreplaceable being that [...] enters this place where it can encounter me, see me, even see me naked [...] here is an existence that refuses to be conceptualized. And a mortal existence, for from the moment that it has a name, its name survives it. It signs its potential disappearance. (Derrida 378-379)

Does Mrs Yeobright "see [her]self seen" through the eyes of the adder, as Arabella later seems to experience upon locking eyes with the pig during the slaughter scene in Jude the Obscure (1895)? Does she recognize something of the adder's "absolute alterity", his "existence that refuses to be conceptualized"? Christian Cantle's use of the gendered pronoun "he" rather than "it" to name the adder - usually reserved for humans in English, as Suzanne Keen notes in relation to the gendered representation of the slaughtered pig in Jude - reiterates the existence of the adder as a named, mortal creature (Keen 376). Ironically, while Mrs Yeobright bitterly felt the refusal of hospitality when Eustacia turned away from her at the window - "I would not have done it against a neighbour's cat on such a fiery day as this!" she tells the young Johnny Nunsuch as he walks with her on the heath (Hardy 2005, 276) - she turns away from the adder much in the same way. Does she recognize her own failure to extend hospitality to another creature? Furthermore, the effect of this rendering of the adder as a creature places the reliability of Mrs Yeobright's perspective in question: not just in relation to her view of the adder in this moment, but with her earlier view of Eustacia and assumption of her daughter-in-law's character and motives.

Whatever the case, this face-to-face confrontation with the adder forces Mrs Yeobright to acknowledge her own exposure and mortality: perhaps it is this recognition that causes her to turn away. Mrs Yeobright and the adder - and Eustacia, as the novel soon reveals are bound by their shared vulnerability, the vulnerability of all living things that is all the more poignant for the fact that in this interspecies face-to-face encounter, the animal is about to be put to death for possible human benefit. The thwarted desire of the animal gazing upon his killers parallels the undercurrent of desire in the relationships between the human characters in the scene (for Mrs Yeobright, the desire to restore her relationship with her son Clym), and the death of the adder marks a turning point in the plot. Mrs Yeobright dies, and shortly thereafter, so does Eustacia.

The linking of these deaths is perhaps appropriate in light of Hardy's view of animals as kin. In a letter written to the Humanitarian League in 1910, he argued for a "readjustment of altruistic morals, by enlarging, as a necessity of rightness, the application of what has been called 'The Golden Rule' from the area of mere mankind to that of the whole animal 
kingdom" (Hardy 2001, 311). Nor did he limit his extension of a primary morality to exclude the snake: in his poem "Drinking Song" the speaker explains,

We all are one with creeping things;

And apes and men

Blood-brethren,

And likewise reptile forms with stings. (Hardy 1976, 906-907)

In his ghosted autobiography, Hardy even included as one of the only anecdotes from his early childhood an instance of being discovered with a large snake curled up with him in his cradle, "comfortably asleep like himself" (Hardy 1984, 19). For Hardy, there is no question that a snake has a face. Although he realized that nonhuman animals might not reciprocate this relationship, he believed humans had an ethical responsibility to all animals.

The characters' (or perhaps readers') failure to recognize the face of the adder - or the ethical demand of his gaze - in The Return of the Native points to a broader failure of human vision. If one must be able, in the words of Levinas, to "place the needs of the other before oneself", to be "unreasonable", in order to qualify as having a face and to be treated with moral consideration, this implies the existence of an always-already possibility of reciprocity. The condition "unreasonable" itself depends upon the fact there is no expectation of return for one's action: if the possibility of reciprocity is a precondition, then such acts could be seen as reasonable. Rather than a lack of a face on the part of the adder, the scene seems to reveal (and perhaps subversively invite) deflection on the part of the human - whether face-to-face with nonhuman or human animals. $^{5}$

In Philosophy and Animal Life, Cary Wolfe and Cora Diamond discuss the role of exposure and deflection in encounters with animals. Wolfe, writing on the work of J. M. Coetzee, points to moments that "acknowledge [...] not only the unspeakability of how we treat animals in practices such as factory farming but also the unspeakability of the limits of our own thinking in confronting such a reality" (Cavell et al. 3). Diamond suggests the phrase "difficulty of reality" to indicate moments in which reality resists thinking, becomes difficult to place into thought or words. She notes that when such moments occur, the result is often deflection, a notion she defines as "what happens when we are moved from the appreciation, or attempt at appreciation, of a difficulty of reality to a philosophical or moral problem apparently in the vicinity" (Cavell et al. 57). Deflection turns away from the present difficult reality to focus on a comprehensible problem that supposedly is related.

While the deflection of the gaze in the scene discussed is literal, Clym's difficulty in grappling with the reality of his mother's death - and his failure to reconcile with her before it - moves him to focus on the supposed "moral problem apparently in the vicinity", that is, Eustacia's refusal to admit Mrs Yeobright to their house - and to admit her suspected infidelity. As he approaches to question her about the day of his mother's death, he meets Eustacia's gaze through the reflection in a mirror, an echo perhaps of Perseus's use of the reflection of his shield to slay Medusa. In their final moments together, Clym intentionally refuses to look at Eustacia, "turn[ing] his eyes aside" as he ties her bonnet strings, her hands too shaky with emotion to accomplish the task herself (Hardy 2005, 319). Faced with the difficult reality of Eustacia's death, Clym becomes withdrawn from and nearly indifferent to the world around him, his deteriorating eyesight an external symptom of an internal loss of vision. 
21 By the end of the novel, Clym's gaze becomes similar to what Berger later calls the look of an animal in the zoo. In the zoo, Berger writes, "the animal's gaze flickers and passes on. They look sideways. They look blindly beyond. They scan mechanically. They have been immunized to encounter, because nothing can any more occupy a central place in their attention" (Berger 37, emphasis original). The animals, he argues, have been "rendered absolutely marginal; and all the concentration you can muster will never be enough to centralize [them]" (34, emphasis original). In this marginal existence, the animals assume an attitude of indifference (35). Likewise, Clym's existence after the deaths of his wife and mother is one of solitude and indifference: he walks the heath alone, is clueless to his cousin's developing romance with the reddleman-turned-dairyman, and has "but three activities alive in him": to visit his mother's grave by day, his wife's by night, and to prepare as a preacher of the "eleventh commandment" (Hardy 2005, 376). When Diggory Venn rescues Thomasin's lost glove, she tells him, “[e]verybody gets so indifferent that I was surprised to know you thought of me" - a phrase revealing of her life as Clym's tenant. Although Clym considers the possible necessity of offering his hand in marriage to Thomasin, he finds that his experiences have rendered all but the presence of his departed mother as marginal, unable to occupy a central place in his attention. Despite his turn as a preacher of the "eleventh commandment" - to love one's neighbour as oneself - Clym ironically never finds his place in the community again.

One might consider the literary relevance of Berger's example of the zoo further. For Berger, the zoo is the site that reveals the "historic loss [...] irredeemable for the culture of capitalism": the completion of the removal of nonhuman animals from human society, at least in places where capitalism has shaped the environment. In turn, this loss also indicates the removal of humans from the rest of the animal world. The human creation of the zoo seems to preserve a relation lost, but as Berger notes, a trip to the zoo often evokes a sense of disappointment. Historically, zoos are sites of imperialism and of scientific knowledge, of power through the demonstration of dominance and the accumulation and compilation of knowledge. Yet we go to the zoo not with the desire to feel dominant or to learn; we go to the zoo expecting something, expecting an encounter. Instead, Berger notes, we are left with the unsaid but often felt question, "[w]hy are these animals less than I believed?" (Berger 33). It is this "unprofessional [...] but fundamental question" that concludes Berger's essay, erecting the zoo as a "living monument" to a dead relationship, to an "irredeemable loss" (36-37).

The zoo is also the site where, according to Berger, animals provide their "last metaphor", with the animals in captivity providing a model for understanding stresses upon humans in consumer societies (Berger 36) ${ }^{6}$. Yet he argues that while "[a]ll sites of enforced marginalization - ghettos, shanty towns, prisons, madhouses, concentration camps - have something in common with zoos [...] it is both too easy and too evasive to use the zoo as a symbol. The zoo is a demonstration of the relations between man and animals; nothing else." Berger begins his essay with a reading of animals as metaphor that asserts the power and similitude of nonhuman animals in relation to human animals, but by the end he emphasizes the zoo as a literal site. This is notable because metaphors have a contentious place in the emerging field of animal studies: as Susan McHugh explains in "One or Several Literary Animal Studies?", the field offers "multiple ways of 
reading animals", but historically "metaphors have been the preponderant (if also most contested) form of literary animals" (McHugh 1-2). Animal studies scholars often "lament the metaphor as the ultimate means of reduction" (McHugh 8): transformed into a metaphor, the individual life of the animal in the text is reduced to a symbol. In contrast, Berger speculates that early animal metaphors were an indicator of the close relationship between human and nonhuman animals. Drawing on Rousseau, he suggests that the first language was likely figurative: attempting to convey a meaning by making a comparison (Berger 16). The essay juxtaposes two passages from the Iliad side by side: similar depictions of a soldier's death and a horse's death in battle (18-19). The overlap then indicates not a reduction of meaning from the animal, but rather a power, in that humans utilized animal comparisons to express meanings that they could not yet articulate in human terms. When humans began to view animals as machines - and later as raw material for human use - the occurrence of metaphor began to flatten animals into symbolic figures, a form of deflection that became habitual for writers and readers. ${ }^{8}$

In conclusion, then, thinking with metaphor can be productive, but to limit a reading to metaphor can be reductive. In the scene between Mrs Yeobright and the adder in The Return of the Native, the adder's metaphorical presence, rendered not only by the depiction of the adder in the text but more importantly by the heath-folk's view of the adder, is relevant. The adder's metaphorical link to Eustacia through the superstition of overlooking suggests a power for the snake writhing in the hut: a mysterious, unknown power. Equally present in the text is a representation of the adder that suggests it is a being living out its own life of value'.

Furthermore, the look between Mrs Yeobright and the adder reminds the reader that the gaze between humans and animals has not been entirely "extinguished", even in the most capitalist of societies (Berger 37). In the Victorian era, the artist Joseph Wolf noted that while the animals in the London Zoo seemed indifferent to the majority of the visitors who stopped by their cages, they responded to his prolonged gaze when he sat outside their enclosures to sketch them, as if to question why he continued to look, why he did not look away (Palmer 188). Animal studies scholar Erica Fudge also points out the many ways animals are still present in human life, especially in the form of pets ${ }^{10}$.

6 Looking at animals in Hardy rewards an extended gaze. His depictions of nonhuman animals engage with many of the philosophical and scientific debates over human-animal boundaries that were taking place in the Victorian era. Notably, Hardy's animals do not appear in his texts simply as mirrors of or companions to the human world. They are more than symbols or movable parts of the landscape; they exist as creatures in their own right, carrying out lives of their own unrelated to the humans they encounter. Their appearance in pivotal scenes exposes characters to the recognition of points of view outside their own, and to the possibility that all may not be as it seems. His animals suggest that there is always more than one way of looking. In the act of looking at these literary animals, one can begin to attribute value not only to what is known and capable of being catalogued, memorized, and recited as forms of knowledge, but to the unknown, to the never-knowable: not just the mysterious or the somehow sacred, but to the acknowledgement of one's own limits and boundaries, to the sense that there are other ways of knowing and being, "Earth-secrets" as the speaker of "An August Midnight" 
suggests (Hardy 1976, 147), animal secrets to paraphrase Berger. Looking at animals in Hardy reminds readers that looking closely does not necessitate a division or loss of attention elsewhere. Rather, it calls for a multiplicity in modes of looking.

\section{BIBLIOGRAPHY}

Berger, John, Why Look at Animals?, New York: Penguin, 2009.

Broglio, Ron, Surface Encounters: Thinking with Animals and Art, Minneapolis: U of Minneapolis P, 2011.

Darwin, Charles, The Expression of the Emotions in Man and Animals, ed. Paul Ekman, $200^{\text {th }}$ anniversary edition, Oxford: OUP, 2009.

Derrida, Jacques, "The Animal That Therefore I am (More to Follow)," trans. David Wills, Critical Inquiry, 28.2 (2002), 369-418.

Cavell, Stanley, Cora Diamond, John McDowell, Ian Hacking, \& Cary Wolfe, Philosophy and Animal Life, New York: Columbia UP, 2008.

Dillion, Jacqueline, Thomas Hardy: Folklore and Resistance, London: Palgrave Macmillan, 2016.

Dillion, Jacqueline \& Phillip Mallett, “'The Evil Eye': Looking and Overlooking in The Return of the Native", Rivista di Studi Vittoriani 38-39 (2014-2015), 7-28. Also published in The Thomas Hardy Journal XXXI (Autumn 2015), 89-107.

Fudge, Erica, Animal, London: Reaktion Books, 2002.

Fudge, Erica, Pets, Stocksfield: Acumen, 2008.

Hagenbeck, Carl, Beasts and Men: Being Carl Hagenbeck's Experiences for Half a Century Among Wild Animals, abridged trans. Hugh S.R. Elliot \& A.G. Thacker, London: Longmans, 1909.

Hardy, Thomas, The Collected Letters of Thomas Hardy, eds. Richard Purdy and Michael Millgate, 7 vols, Oxford: Clarendon Press, 1978-1988.

Hardy, Thomas, The Complete Poems of Thomas Hardy, ed. James Gibson, London: Macmillan, 1976. Hardy, Thomas, The Life and Work of Thomas Hardy, ed. Michael Millgate, London: Macmillan, 1984.

Hardy, Thomas, Thomas Hardy's Public Voice: The Essays, Speeches, and Miscellaneous Prose, ed. Michael Millgate, Oxford: Clarendon Press, 2001.

Hardy, Thomas, The Return of the Native (1878), ed. Simon Gatrell, Oxford: OUP, 2005.

Keen, Suzanne, "Empathetic Hardy: Bounded, Ambassadorial, and Broadcast Strategies of Narrative Empathy," Poetics Today 32.2 (Summer 2011), 349-389.

Levinas, Emmanuel, Totality and Infinity: An Essay on Exteriority, trans. Alphonso Lingis, Pittsburgh: Duquesne UP, 1969.

Levine, George, Darwin and the Novelists: Patterns of Science in Victorian Fiction, Cambridge, MA: Harvard UP, 1988. 
McHugh, Susan, “One or Several Literary Animal Studies?" H-Animal (2015), 1-13 <https:// networks.h-net.org/node/16560/pages/32231/one-or-several-literary-animal-studies-susanmchugh> (last accessed 15 Jan 2017).

Miller, J. Hillis, Thomas Hardy: Distance and Desire, London: OUP, 1970.

Morse, Deborah Denenholz \& Martin A. Danahay (eds.), Victorian Animal Dreams: Representations of Animals in Victorian Literature and Culture, Surrey: Ashgate, 2007.

Palmer, A. H., The Life of Joseph Wolf: Animal Painter, London: Longmans, 1895.

Ramel, Annie, “Tess the Murderess, Eustacia the Adder: Two Women 'Criminals' in Hardy's Fiction", Fiction, Crime, and the Feminine, eds. Rédouane Abouddahab \& Josiane Paccaud-Huguet, Newcastle upon Tyne: Cambridge Scholars, 2011.

Ramel, Annie, The Madder Stain: A Psychoanalytic Reading of Thomas Hardy, Boston: Brill Rodopi, 2015.

Shakespeare, William, King Lear, ed. R.A. Foakes, London: Arden Shakespeare, 2001.

Wright, Tamra, Peter Hughes \& Alison Ainley, "The Paradox of Morality: An Interview with Emmanuel Levinas", The Provocation of Levinas: Rethinking the Other, eds. Robert Bernasconi \& David Wood, London: Routledge, 1988, 168-180.

\section{NOTES}

1. In Darwin and the Novelists, Levine argues, "[w]hat observation reveals is one's own marginality and vulnerability" (Levine 232).

2. As others have noted, this scene recalls Shakespeare's King Lear, both in the use of a hovel to escape the heath and in the frying of the adders, which links to the fool's story of cooking eels alive (II. 2. 310-314).

3. Mrs Yeobright's wound from the adder bite further connects Eustacia to this scene through the image of the bloodstain, as Annie Ramel explores in The Madder Stain (Ramel $2015,101)$.

4. Christian sees the adder as a descendent of the serpent in the Garden of Eden, wondering if "something of the old serpent in God's garden, that gied the apple to the young woman with no clothes, lives on in adders and snakes still?" (Hardy 2005, 285). Mixing Biblical stories with folklore, he resolves that he "will never kill another adder as long as [he] lives" - a statement that seems in some way to recognize the ethical demand of the adder's gaze.

5. The terms "human animal" and "nonhuman animal" are often used in animal studies as a reminder that both exist within the same animal kingdom. See Erica Fudge's conclusion to Animal , 159-165 and Morse \& Danahay's introduction to Victorian Animal Dreams, 2. Hardy himself used the term "nonhuman animal" in letters to friends (Collected Letters, iii, 232).

6. Berger refers to the zoologist Desmond Morris's The Naked Ape (1967) and The Human Zoo (1969).

7. Berger extends this thought for a moment to the possible "marginalization and disposal of" the "middle and small peasant" classes, expanding on his earlier idea that "[t]he reduction of the animal, which has a theoretical as well as economic history, is part of the same process as that by which men have been reduced to isolated productive and consuming units [...] an approach to animals often prefigured an approach to man" (Berger 36, 23). 
8. Perhaps this is why animal metaphors work so well in satirical writing, where the anthropocentric viewpoint becomes exaggerated for comedic effect.

9. One might think of Berger's concept of being naked versus the nude here. While literary animals such as the adder may exist as naked creatures - as themselves, without disguise humans have often constructed the animal as a nude: an object for appropriation and use as an object (for example, as a metaphor).

10. Fudge points out that Berger's rendering of pets as "somehow not fully animal" in his essay is problematic, as it suggests a "category of the authentic animal" (Fudge 24). She also argues that Berger's suggestion that pets are "deprived of almost all other animal contact" demonstrates a way his essay is undercut by a humanist "notion of the human as separate from animals" (given that pets are in nearly constant contact with the animal species Homo sapiens) (24).

\section{ABSTRACTS}

In his essay "Why Look at Animals?" art critic John Berger discusses the gaze between humans and animals. He argues that while the gaze of animals has the power to surprise humans (who see themselves being seen through the animals' eyes), this look has been "extinguished" with the marginalization of animals from society. In Thomas Hardy's novels, humans who encounter animals face-to-face and eye-to-eye often find themselves uncomfortable being seen through the gaze of the animal. In The Return of the Native (1878), for example, Mrs Yeobright shudders under the gaze of the adder. While Berger argues for the importance of metaphor in restoring the human-animal relationship, the adder in the scene can be read not only as a metaphor for the absent-yet-implicated Eustacia, but also as a living being in its own right. Of significance to this paper is the refusal of the human-animal gaze that occurs during the encounter: the turning away, or the desire not to see oneself being seen through the eyes of another, a desire that also occurs during interactions between humans in the novel. What happens to desire when the gaze flickers, is deflected, or becomes indifference? Furthermore, how might this affect the way we look at-or away from-literary animals?

Dans son essai "Pourquoi regarder les animaux?", le critique d'art John Berger aborde la question de l'échange de regards entre les hommes et les animaux. Il remarque que le regard des animaux a la capacité de surprendre les hommes (qui se voient eux-mêmes vus à travers les yeux des animaux), mais que ce regard a été "nié » par la marginalisation des animaux dans nos sociétés. Dans les romans de Thomas Hardy, les êtres humains qui se trouvent confrontés à des animaux, face à face, et les yeux dans les yeux, ressentent souvent une forme de malaise à se voir vus par les yeux des animaux en question. Ainsi, dans The Return of the Native (1878), Mrs Yeobright frissonne sous le regard de la vipère. Même si Berger souligne l'importance des métaphores dans le processus visant à rétablir des relations entre l'homme et l'animal, la vipère ne peut pas être interprétée uniquement comme métaphore rappelant le personnage de Eustacia, à ce moment-là absente de la scène : car elle est aussi et surtout un être vivant à part entière. Cet article se concentre sur le refus de l'échange de regards entre l'homme et l'animal dans cette confrontation : Mrs Yeobright se détourne, comme mue par le désir de ne pas être vue à travers les yeux de l'autre - un désir qui dans ce roman se manifeste également dans les relations entre humains. Que se passe-t-il lorsque le regard tremble, ou se détourne, ou devient indifférent ? Et 
surtout, comment ce type de scène peut-il influencer la manière dont nous regardons les animaux, ou nous en détournons?

INDEX

Keywords: gaze, desire, adder, animal, metaphor, deflection, faces oeuvrecitee Return of the Native (The)

Mots-clés: animal, évitement, regard, désir, vipère, visage, vue

\section{AUTHOR}

ANNA WEST

Anna West is an early career researcher whose work focuses on Thomas Hardy and animal studies. She received her PhD from the University of St Andrews. Her first monograph, Thomas Hardy and Animals, was published by Cambridge University Press in 2017. 